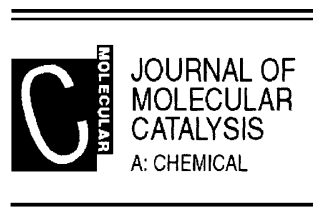

Journal of Molecular Catalysis A: Chemical 174 (2001) 265-277

www.elsevier.com/locate/molcata

\title{
Acidity and reactivity of trifluoromethanesulfonic acid in liquid and solid acid catalysts
}

\author{
Nunziata Clara Marziano*, Lucio Ronchin, Claudio Tortato, \\ Armando Zingales, Abdiqafar A. Sheikh-Osman \\ Chemistry Department, University of Venice, DorsoDuro 2137, 30123 Venice, Italy
}

Received 23 January 2001; accepted 17 April 2001

\begin{abstract}
The acidic properties of $\mathrm{CF}_{3} \mathrm{SO}_{3} \mathrm{H} / \mathrm{SiO}_{2}$ acid catalysts have been investigated by the protonation of weak bases (B) $\left(\mathrm{B}+\mathrm{H}^{+} \rightleftharpoons \mathrm{BH}^{+}\right)$and the proton-transfer process from $\left(\mathrm{H}^{+} \mathrm{A}^{-}\right)$to $\left(\mathrm{BH}^{+} \mathrm{A}^{-}\right)$has been analysed by a thermodynamic procedure used to account the variation of the activity coefficient terms of the species involved. Acid-base systems with different substituted pyridines as back-titrating agents of $\mathrm{BH}^{+}$(i.e. $\mathrm{BH}^{+} \rightarrow$ B) have also been studied and the changes observed in the acid-base interactions according to basicity of pyridines are discussed. The results in solid phase have been compared with those observed in concentrated aqueous solutions (i.e. $\mathrm{CF}_{3} \mathrm{SO}_{3} \mathrm{H}+\mathrm{H}_{2} \mathrm{O}$ ) where "acidity" and "protonating ability" have been distinguished as parameters of interest in the description of nonideal acid systems.

Silica loaded with $\mathrm{CF}_{3} \mathrm{SO}_{3} \mathrm{H}$, with $\mathrm{H}_{2} \mathrm{SO}_{4}$ and with a mixture of both acids have been tested in acid catalysed reactions and their catalytic effectiveness has been explored towards substrates with high acid requirements for the conversion reagents-products. From the available observations in liquid and in solid phase, $\mathrm{CF}_{3} \mathrm{SO}_{3} \mathrm{H}$ has been proved to be a less effective acid catalyst than expected from the observed protonating ability of acidic medium. Strong interactions between ionic species and the involvement of ion-pairs in concentrated acid systems have been suggested. ( 2001 Elsevier Science B.V. All rights reserved.
\end{abstract}

Keywords: Trifluoromethanesulfonic acid; Surface acidity; Acid catalysis

\section{Introduction}

Trifluoromethanesulfonic acid (TFMSA or triflic acid) is known to be a strong acid suitable to be used as catalyst for synthetic applications [1-9]. The design of acid-catalysed reactions over solids has caused a pronunced need for further researchs in this area and supported triflic acid [10-14] or materials with $-\mathrm{CF}_{2} \mathrm{SO}_{3} \mathrm{H}$ groups $[9,15-18]$ are becoming now available to replace homogeneous acid solutions.

\footnotetext{
* Corresponding author. Fax: +39-41-257-8517.

E-mail address: marziano@helios.univ.it (N.C. Marziano).
}

Measurements of catalytic performance and surface acidity have also been developed to enhance the understanding of the phenomena relating acidity and catalytic reactivity $[19,20]$.

From experimental data obtained using the Hammett acidity functions $[21,22]$ it appears that TFMSA and perfluorinated acid resins are superacids with $H_{0}$ values between -12 and -14 in the scale of superacidity ranging between -10 and $-20[2,9,15-18]$.

However, new studies [23-26] have shown that the $H_{0}$ scale, largely used as a measure of acidity in acids and superacids is, on the contrary, a source of discrepancies and uncertainties in the practical applications. 
In sulfuric, percloric, nitric, triflic, methanesulfonic acids, for instance, the available $H_{0}$ (or $H_{x}$ ) acidity functions have been found to be unrelated to acidity of medium.

In the present paper, the acidic properties of supported triflic acid (i.e. $\mathrm{CF}_{3} \mathrm{SO}_{3} \mathrm{H} / \mathrm{SiO}_{2}$ ) are determined by following the protonation of weak bases $(\mathrm{B} \rightarrow$ $\mathrm{BH}^{+}$) involved in the acid-base processes. Additional knowledges of acid-base interactions are obtained by adding different substituted pyridines as back titrating agents of $\mathrm{BH}^{+}$species (i.e. $\mathrm{BH}^{+} \rightarrow \mathrm{B}$ ). The experimental observations in solid are compared to those obtained in analogous aqueous acids (i.e. $\mathrm{CF}_{3} \mathrm{SO}_{3} \mathrm{H}+$ $\mathrm{H}_{2} \mathrm{O}$ ) where a large number of experimental data related to medium acidity are already known [23,27-30]. In this phase, "acidity" and "protonating ability" have been recognised as two different parameters suitable to describe non-ideal acid systems.

Materials loaded both with triflic and with sulfuric acids have also been tested as catalysts for chemical transformations and the results have been compared with the experimental observations obtained in analogous aqueous acid solutions. The relative catalytic performance is of interest since early reports in aqueous phase show that the nitration rates were found to be lower in triflic than in sulfuric acid. It has been suggested that complications due to ion-pairs can affect equilibria and rates although the undesiderable side reactions affecting the results in sulfuric acid are avoided [23,27,31].

\section{Experimental}

\subsection{Materials}

Purified samples of commercially available GRACE Silica Gel $\left(90 \mu \mathrm{m}\right.$ average particle size, $\left(S_{\mathrm{BET}}\right)$ $364 \mathrm{~m}^{2} / \mathrm{g}, 1.14 \mathrm{ml} / \mathrm{g}$ pore volume) were obtained by washing the material with aqueous solutions of perchloric acid, then with distilled water. Reagents and solvents (i.e. $\mathrm{CF}_{3} \mathrm{SO}_{3} \mathrm{H}$, indicators, pyridines, cyclohexane, etc.) were used after purification of the commercially available samples and their purity was checked by the usual methods (mp's, TLC, HPLC, GLC). The aqueous acid solutions were prepared by diluting fresh distilled samples of $\mathrm{CF}_{3} \mathrm{SO}_{3} \mathrm{H}$ and their percentage composition was determined by potentiometric titration against standard solutions of $\mathrm{NaOH}$.

\subsection{Preparation and characterisation of the catalysts}

Samples of catalysts were prepared by using aqueous and non aqueous acid solutions. In the first case, weighted amounts of purified silica gel was mixed with a known amount of aqueous solution of acids of appropriate concentration. After stirring for $1 \mathrm{~h} \mathrm{ca}$. the surnatant solution was removed by filtration and the wet catalyst was dried for $72 \mathrm{~h}$ at $105^{\circ} \mathrm{C}$ in a stream of $\mathrm{N}_{2}$, then stored in a dry apparatus.

In the second case, weighted amounts of purified silica gel was mixed with a known amount of the acid mixtures (i.e. $\mathrm{CH}_{2} \mathrm{Cl}_{2}+\mathrm{CH}_{3} \mathrm{NO}_{2}+$ acid). The solvents were removed under stirring at room temperature for $3 \mathrm{~h}$ and at $105^{\circ} \mathrm{C}$ for $18 \mathrm{~h}$ under nitrogen flow, then stored in a dry apparatus.

Samples of $\mathrm{CF}_{3} \mathrm{SO}_{3} \mathrm{H}, \mathrm{H}_{2} \mathrm{SO}_{4}$ and mixtures of them supported on silica have been tested. The acid percentage composition in the solids after impregnation was determined by potentiometric titrations against standard solutions of $\mathrm{NaOH}$ and checked before use. It avoid the uncertainties due to hygroscopicity of the catalysts, particularly high for samples of $\mathrm{CF}_{3} \mathrm{SO}_{3} \mathrm{H} / \mathrm{SiO}_{2}$.

The BET surface area (SA), pore size distribution (BJH model) and total pore volume (relative pressure of $p / p_{0}=0.98$ ) of the catalysts have been determined by $\mathrm{N}_{2}$ adsorption and desorption at $94 \mathrm{~K}$ using an automatic adsorption unit (Micromeritics ASAP 2010C). The type of acid sites has been characterised by XPS measurements using pyridine chemisorption and investigation of the $\mathrm{N}_{1 \mathrm{~s}}$ XPS band [32].

\subsection{UV measurements}

A stock solution of indicator (B), prepared by dissolving a weighed sample in a weighed amount of anhydrous cyclohexane (ca. $10^{-4}$ and $10^{-3} \mathrm{~mol} \mathrm{dm}^{-3}$ ), was added to a known amount of catalyst. After at least $2 \mathrm{~h}$, the sample was transferred in a UV cell of $0.1 \mathrm{~cm}$ and subjected to centrifugation at $270 \times g$ for $10 \mathrm{~min}$ together with an analogous reference cell, filled with catalyst + cyclohexane.

The UV absorbance was measured at $25^{\circ} \mathrm{C}$ following the spectral changes $\left(\mathrm{B} \rightarrow \mathrm{BH}^{+}\right.$) over $\mathrm{CF}_{3} \mathrm{SO}_{3} \mathrm{H} / \mathrm{SiO}_{2}$ samples with acid loadings between 0.05 and $0.5 \mathrm{mmol} \mathrm{CF} \mathrm{SO}_{3} \mathrm{H} / \mathrm{g}_{\text {catalyst }}$. 
The molar extinction coefficients $(\varepsilon)$ were calculated from the absorbance. Calibration plots in cyclohexane were used for determining the stoichiometric concentrations of the residual indicator in the solvent.

The ionisation ratios $\left[\mathrm{BH}^{+}\right] /[\mathrm{B}]$ were calculated from the $\left(\varepsilon_{\mathrm{B}}-\varepsilon_{\text {obsd }}\right) /\left(\varepsilon_{\mathrm{obsd}}-\varepsilon_{\mathrm{BH}^{+}}\right)$values. The molar extinction coefficients of the unprotonated $\left(\varepsilon_{\mathrm{B}}\right)$ and protonated $\left(\varepsilon_{\mathrm{BH}^{+}}\right)$forms were obtained, respectively, at very low acid concentrations and in acid mixtures where the observed protonation was $>99 \%$. 2-Cl-4- $\mathrm{NO}_{2}$-aniline and 2,4-diCl-6- $\mathrm{NO}_{2}$-aniline were used as indicators and the spectral changes from unprotonated to protonated form were followed at selected wavelengths between 370 and $420 \mathrm{~nm}$.

The UV measurements of solid acid samples with starting acid loadings of $0.5 \mathrm{mmol} \mathrm{CF} 3 \mathrm{SO}_{3} \mathrm{H} / \mathrm{g}_{\text {catalyst }}$ for 2-Cl-4- $\mathrm{NO}_{2}$-aniline and of $0.8 \mathrm{mmol} \mathrm{CF}_{3} \mathrm{SO}_{3}$ $\mathrm{H} / \mathrm{g}_{\text {catalyst }}$ for 2,4-diCl-6- $\mathrm{NO}_{2}$-aniline were also performed. In these range of acid loadings the protonated form of indicators is observed $[33,34]$. Therefore, the addition of some pyridines as back titrating bases of indicators allows the experimental observation of the equilibria $\left(\mathrm{BH}^{+} \rightarrow \mathrm{B}\right)$ in the solid acid mixtures. The samples were prepared as already described, but were equilibrated by shaking for $24 \mathrm{~h}$ before measurements.

Unsubstituted pyridine was used as back titrating base of protonated 2-Cl-4- $\mathrm{NO}_{2}$-aniline. Different substituted pyridines: i.e. 2,6-di-Me-, 2-Me-, 3-Me-, 4-Me-, $\mathrm{H}-$, 3-Cl- were used for an analogous study of protonated 2,4-diCl-6- $\mathrm{NO}_{2}$-aniline.

\subsection{Acid catalysed reactions}

Nitration and esterification of aromatic compounds over $\mathrm{CF}_{3} \mathrm{SO}_{3} \mathrm{H} / \mathrm{SiO}_{2}$ have essentially been tested in the study of reactivity. In a typical run of nitration, a solution of substrate in dry dichloromethane was added to $0.5 \mathrm{~g}$ of activated catalyst in a thermostated reactor at $25^{\circ} \mathrm{C}$. Then, the nitrating agent was added dropwise and the obtained slurry was stirred for an appropriate time. The supernatant solution was analysed by GC and GC-MS. In a typical run of esterification, separate solutions of mesitoic acid and methanol in toluene of appropriate concentrations were added to $0.5 \mathrm{~g}$ of activated catalyst in a thermostated reactor at $70^{\circ} \mathrm{C}$. The supernatant solution was analysed by HPLC using a Lichrospher 100 (Rp-18, 5 m) column and a Perkin-Elmer apparatus. The mixture at the end of reaction was also detected by GC and GCMS.

Additional tests of reactivity have analogously been performed for comparisons, by using samples both of $\mathrm{H}_{2} \mathrm{SO}_{4} / \mathrm{SiO}_{2}$ and of $\left(\mathrm{CF}_{3} \mathrm{SO}_{3} \mathrm{H}+\mathrm{H}_{2} \mathrm{SO}_{4}\right) / \mathrm{SiO}_{2}$.

\section{Results and discussion}

\subsection{Analysis of the catalytic materials}

Solid acid catalysts with well known amounts of acid and well characterised types of acid sites offer an attractive simple means for a number of studies in the solid phase. Samples of $\mathrm{CF}_{3} \mathrm{SO}_{3} \mathrm{H} / \mathrm{SiO}_{2}$ with different acid loadings are, then, investigated for measurements of acidity and catalytic performance and in Table 1, the effects of varying the amount of acid on the physical properties of the catalysts are reported. Additional data obtained by using samples of $\mathrm{H}_{2} \mathrm{SO}_{4} / \mathrm{SiO}_{2}$ and $\left(\mathrm{CF}_{3} \mathrm{SO}_{3} \mathrm{H}+\mathrm{H}_{2} \mathrm{SO}_{4}\right) / \mathrm{SiO}_{2}$ are enclosed for comparison.

The results show a progressive decrease of surface area and of total pore volume as increases the acid loading whereas pore size distribution exhibit a constant average diameter of ca. $8 \mathrm{~nm}$. An excess of water allows the complete leaching of acid without changing the silica framework. It appears on the control of the resulting materials whose values of surface area and porosity are analogous to the ones observed in the starting sample.

Further details related to type of acid sites have been obtained by XPS measurements. On the analysis by pyridine chemisorption and investigation of the $\mathrm{N}_{1 \mathrm{~s}}$ XPS band, all the samples exhibit a single peak at $401 \mathrm{eV}$ due to the presence of Brøensted acid sites. On the analysis by the XPS peak areas of Si (2p) and $\mathrm{S}(2 \mathrm{p})$,the $\mathrm{Si} / \mathrm{S}$ ratios of the catalysts loaded with $\mathrm{H}_{2} \mathrm{SO}_{4}$ were found to be proportional to the amount of sulfuric acid added to silica gel. In addition, a sample loaded with $4.65 \mathrm{mmol} \mathrm{H}_{2} \mathrm{SO}_{4} / \mathrm{g}_{\text {catalyst }}$ analysed by a microRaman spectrum, shows the band at $981 \mathrm{~cm}^{-1}$ of $\mathrm{SiO}_{2}(\mathrm{SiOH}$ stretching mode of isolated surface silanol species) [35] and the band at $1044 \mathrm{~cm}^{-1}$ of bisulfate ion [36].

The results suggest that (i) the strong Brøensted acid sites observed on the catalyst are due to the added acids, (ii) the isolated silanol groups are due to 
Table 1

Properties of the catalysts

\begin{tabular}{|c|c|c|c|c|c|c|c|c|c|c|c|}
\hline \multicolumn{4}{|c|}{$\mathrm{CF}_{3} \mathrm{SO}_{3} \mathrm{H} / \mathrm{SiO}_{2}$} & \multicolumn{4}{|c|}{$\mathrm{H}_{2} \mathrm{SO}_{4} / \mathrm{SiO}_{2}$} & \multicolumn{4}{|c|}{$\left(\mathrm{CF}_{3} \mathrm{SO}_{3} \mathrm{H}+\mathrm{H}_{2} \mathrm{SO}_{4}\right) / \mathrm{SiO}_{2}$} \\
\hline$(\mathrm{wt} . \%)^{\mathrm{a}}$ & $\begin{array}{l}(\mathrm{mmol} / \\
\left.\mathrm{g}_{\text {catalyst }}\right)^{\mathrm{b}}\end{array}$ & $\begin{array}{l}\text { BET surface } \\
\text { area }^{\text {c }}\end{array}$ & $\begin{array}{l}\text { Total pore } \\
\text { volume }^{\mathrm{d}}\end{array}$ & $(\mathrm{wt} . \%)^{\mathrm{a}}$ & $\begin{array}{l}(\mathrm{mmol} / \\
\left.\mathrm{g}_{\text {catalyst }}\right)^{\mathrm{b}}\end{array}$ & $\begin{array}{l}\text { BET surface } \\
\text { area }^{\text {c }}\end{array}$ & $\begin{array}{l}\text { Total pore } \\
\text { volume }^{\mathrm{d}}\end{array}$ & $(\mathrm{wt} . \%)^{\mathrm{a}}$ & $\begin{array}{l}(\mathrm{meq} / \\
\left.\mathrm{g}_{\text {catalyst }}\right)^{\mathrm{b}}\end{array}$ & $\begin{array}{l}\text { BET surface } \\
\text { area }^{c}\end{array}$ & $\begin{array}{l}\text { Total pore } \\
\text { volume }^{\mathrm{d}}\end{array}$ \\
\hline & 0 & 364 & 1.0 & & 0 & 364 & 1.0 & & 0 & 364 & 1.0 \\
\hline $7.5^{\mathrm{e}}$ & 1.1 & 227 & 0.72 & 10 & 3.8 & 291 & 0.88 & $10+20$ & 3.4 & 230 & 0.73 \\
\hline $7.5^{\mathrm{e}}$ & 2.3 & 130 & 0.43 & 18 & 6.3 & 214 & 0.71 & & 6.6 & 183 & 0.58 \\
\hline \multirow[t]{4}{*}{$7.5^{\mathrm{e}}$} & 3.3 & & & 21 & 6.6 & 182 & 0.67 & & & & \\
\hline & & & & 28 & 8.3 & 136 & 0.36 & & & & \\
\hline & & & & 30 & 8.7 & 108 & 0.33 & & & & \\
\hline & & & & 38 & 10.1 & 80 & 0.18 & & & & \\
\hline
\end{tabular}

a Percentage of acid in the starting aqueous solution.

${ }^{\mathrm{b}}$ Amount of acid determined in the solid catalyst.

${ }^{c}$ BET surface area $\mathrm{m}^{2} / \mathrm{g}$; (slope of surface area vs. meq $/ \mathrm{g}_{\text {catalyst }}=-101.5$ (in $\left.\mathrm{CF}_{3} \mathrm{SO}_{3} \mathrm{H} / \mathrm{SiO}_{2}\right) ;-29.5\left(\right.$ in $\left.\mathrm{H}_{2} \mathrm{SO}_{4} / \mathrm{SiO}_{2}\right) ;-27.6\left(\right.$ in $\left(\mathrm{CF}_{3} \mathrm{SO}_{3} \mathrm{H}+\mathrm{H}_{2} \mathrm{SO}_{4}\right) / \mathrm{SiO}_{2}$.

d Total pore volume by $\mathrm{N}_{2}$ adsorption at $p / p_{0}=0.98 \mathrm{ml} / \mathrm{g}$.

e Percentage of acid in the starting non aqueous solution $\left(\mathrm{CH}_{2} \mathrm{Cl}_{2}+\mathrm{CH}_{3} \mathrm{NO}_{2}\right)$. 
incomplete coverage of the surface; (iii) the acids fill the pore in proportion to the amount of the acid loadings, (iv) the changes of surface area, as increase the acid loadings, are dependent on the type of the starting acid used for the impregnation (i.e. $\mathrm{CF}_{3} \mathrm{SO}_{3} \mathrm{H} / \mathrm{SiO}_{2}>$ $\left.\mathrm{H}_{2} \mathrm{SO}_{4} / \mathrm{SiO}_{2} \approx\left(\mathrm{CF}_{3} \mathrm{SO}_{3} \mathrm{H}+\mathrm{H}_{2} \mathrm{SO}_{4}\right) / \mathrm{SiO}_{2}\right)($ see Table 1).

\subsection{Protonation studies in $\mathrm{CF}_{3} \mathrm{SO}_{3} \mathrm{H} / \mathrm{SiO}_{2}$}

The protonation of weak bases (B) (equilibrium 1) is a procedure widely applied to detect the acidic properties of acid systems [21-26].

$\mathrm{B}+\mathrm{H}^{+} \rightleftharpoons \mathrm{BH}^{+}$

It suggested a number of studies over $\mathrm{CF}_{3} \mathrm{SO}_{3} \mathrm{H} / \mathrm{SiO}_{2}$ with different acid loadings and UV measurements related to conversion $\mathrm{B} \rightarrow \mathrm{BH}^{+}$of different ni- troanilines used as indicators. The results show that 2,Cl-4-nitroaniline and 2,4-diCl-6-nitroaniline can be easily protonated by samples with acid loadings between 0.05 and $0.5 \mathrm{mmol} \mathrm{HA} / \mathrm{g}_{\text {catalyst }}$ (see Fig. 1). Analogous trend has been observed in the protonation of analogous indicators over $\mathrm{HClO}_{4} / \mathrm{SiO}_{2}$ and $\mathrm{H}_{2} \mathrm{SO}_{4} / \mathrm{SiO}_{2}$ [24,34].

The experimental data obtained (i.e. titration curves and $\left[\mathrm{BH}^{+}\right] /[\mathrm{B}]$ ratios), have been analysed by the thermodynamic Eq. (2) rewritten as (3), where the activity coefficients of reagents and products involved in the equilibria are taken into account (see Eq. (4)).

$$
\begin{aligned}
& \mathrm{p} K_{\mathrm{BH}^{+}}=\log \frac{\left[\mathrm{BH}^{+}\right]}{[\mathrm{B}]}-\log \left[\mathrm{H}^{+}\right]-\log \left(\frac{f_{\mathrm{B}} f_{\mathrm{H}^{+}}}{f_{\mathrm{BH}^{+}}}\right) \\
& \mathrm{p} K_{\mathrm{BH}^{+}}=\log \frac{\left[\mathrm{BH}^{+}\right]}{[\mathrm{B}]}-\log \left[\mathrm{H}^{+}\right]+b\left[C_{\mathrm{A}}\right]
\end{aligned}
$$



Fig. 1. Protonation equilibria of 2,4-diCl-6- $\mathrm{NO}_{2}$-aniline over $\mathrm{CF}_{3} \mathrm{SO}_{3} \mathrm{H} / \mathrm{SiO}_{2}$ without $\left(\mathrm{B} \rightarrow \mathrm{BH}^{+}\right)$and with pyridine $\left(\mathrm{BH}{ }^{+} \rightarrow \mathrm{B}\right)(\triangle)$ percentage of 2,4-diCl-6- $\mathrm{NO}_{2}$-aniline vs. $\mathrm{CF}_{3} \mathrm{SO}_{3} \mathrm{H} / \mathrm{SiO}_{2} ;(\mathrm{O})$ percentage of 2,4-diCl-6- $\mathrm{NO}_{2}$-aniline vs. pyridine using a catalyst with $0.75 \mathrm{mmol} \mathrm{acid} / \mathrm{g}_{\text {catalyst }}$. 
$-\log \left(\frac{f_{\mathrm{B}} f_{\mathrm{H}^{+}}}{f_{\mathrm{BH}^{+}}}\right)=b\left[C_{\mathrm{A}}\right]$

From a practical point of view, $\mathrm{p} K_{\mathrm{BH}^{+}}(-0.90$ and $-3.50)$ and $b\left(5.5 \times 10^{4}\right.$ and $\left.3.7 \times 10^{4}\right)$ values have been estimated related, respectively, to the intercepts and slopes of the plots $\left(\log \left[\mathrm{BH}^{+}\right] /[\mathrm{B}]-\log \left[\mathrm{H}^{+}\right]\right)$versus $\left[C_{\mathrm{A}}\right] ;\left(\left[C_{\mathrm{A}}\right]=\right.$ acid concentration $)$.

The $\mathrm{p} K_{\mathrm{BH}^{+}}$values, equal to the previous estimates in solids (i.e. $\mathrm{HClO}_{4} / \mathrm{SiO}_{2}, \mathrm{H}_{2} \mathrm{SO}_{4} / \mathrm{SiO}_{2}$ ) [24,34] and in aqueous solutions (i.e. $\mathrm{H}_{2} \mathrm{SO}_{4}, \mathrm{HClO}_{4}, \mathrm{HCl}$, $\mathrm{CH}_{3} \mathrm{SO}_{3} \mathrm{H}, \mathrm{HNO}_{3}$ ) [23-26] suggest that the catalysts
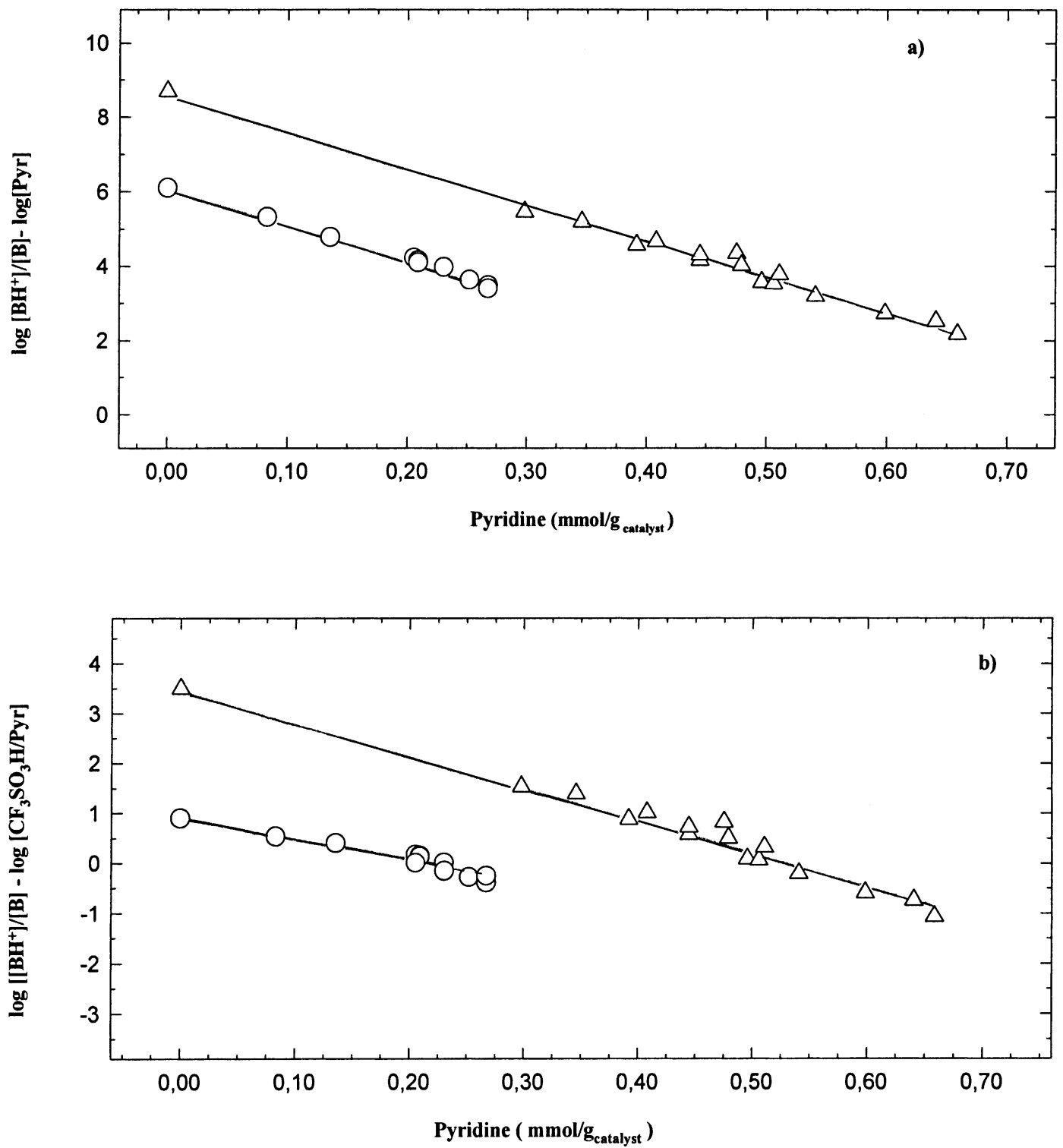

Fig. 2. Back titration of nitroanilines by Pyridine in $\mathrm{CF}_{3} \mathrm{SO}_{3} \mathrm{H} / \mathrm{SiO}_{2}$ at $25^{\circ} \mathrm{C}$. (a) Plot of $\log \left[\mathrm{BH}{ }^{+}\right] /[\mathrm{B}]-\log [\mathrm{Pyr}]$ vs. [Pyr $]$ of 2-Cl-4- $\mathrm{NO}_{2}$-aniline $(\mathrm{O})$ and 2,4-diCl-6- $\mathrm{NO}_{2}$-aniline $(\triangle)$. (b) Plot of $\log \left[\mathrm{BH}^{+}\right] /[\mathrm{B}]-\log \left[\mathrm{CF}_{3} \mathrm{SO}_{3} \mathrm{H} / \mathrm{Pyr}\right]$ vs. $[\mathrm{Pyr}]$ of $2-\mathrm{Cl}-4-\mathrm{NO}{ }_{2}$-aniline $(\mathrm{O})$ and 2,4-diCl-6- $\mathrm{NO}_{2}$-aniline $(\triangle)$. 
under investigation exhibit one type of acid site and thermodynamic constants that can be referred to water as standard state. The efficiency of the catalyst can be inferred from the slopes values, higher by a factor of ca. $10^{4}$ to $10^{5}$ compared to the ones observed for the same indicators in aqueous acid solutions using an analogous procedure [23-26].

Further informations have been gained from the experimental data obtained by using acid samples with the acid form of the indicators (i.e. $\mathrm{CF}_{3} \mathrm{SO}_{3} \mathrm{H} / \mathrm{SiO}_{2}+$ $\mathrm{BH}^{+}$) as starting point of the measurements and different substituted pyridines (Pyr) as back titrating agents of $\mathrm{BH}^{+}$. The new titration curves, determined by following the variations $\left(\mathrm{BH}^{+} \rightarrow \mathrm{B}\right)$ of the indicator (see Fig. 1), have been analysed by a modified form of Eq. (3) where the protonation equilibrium of pyridines $\left(\mathrm{Pyr} \rightarrow \mathrm{PyrH}^{+}\right)$and the new acid-base interactions have essentially be taken into account. For instance, by using the (A) plots: $\log \left[\mathrm{BH}^{+}\right] /[\mathrm{B}]-\log [\mathrm{Pyr}]$ versus [Pyr], an intercept $=-\mathrm{p} K_{\mathrm{BH}^{+}}+\mathrm{p} K_{\mathrm{PyrH}^{+}}$ is observed (see Fig. 2a); by using the (B) plots: $\log \left[\mathrm{BH}^{+}\right] /[\mathrm{B}]-\log \left[\mathrm{CF}_{3} \mathrm{SO}_{3} \mathrm{H} / \mathrm{Pyr}\right]$ versus [Pyr] an intercept $=-\mathrm{p} K_{\mathrm{BH}^{+}}$is observed (see Fig. 2b).

The pyridines analysed, the indicators used and the parameters obtained in this study by the plots A and $\mathrm{B}$ are reported in Table 2.
For 4-Me-, 3-Me-, 3-Cl- and unsubstituted pyridine used as back titrating agents of 2,4-diCl-6- $\mathrm{NO}_{2}$-aniline, a further analysis of the results show that:

1. the slope values obtained by the (A) and (B) plots are found to be linealy related to the corresponding meta- and para- " $\sigma$ constants" of substituted pyridines;

2. the slope values obtained by the (B) plots are found to be linearly related to the corresponding $\mathrm{p} K_{\mathrm{PyrH}^{+}}$ values of the pyridines;

3. the linear dependence obtained by the (B) plots, for slope values $\rightarrow 0$, can be referred to $\mathrm{p} K_{\mathrm{BH}^{+}}$value $(-3.50)$ of indicator used for the measurement.

Slopes and $\mathrm{p} K_{\mathrm{PyrH}^{+}}$of 2-Me- and of 2,6-di Me-pyridine, where additional interactions due to the orthosubstitution are expected, are found to be unrelated to behaviour of meta- and para-substituted pyridines.

In Fig. 3, the linear free energy relationship (LFER) observed between slopes and $\mathrm{p} K_{\mathrm{PyrH}^{+}}$for the system (acid $+\mathrm{BH}^{+}+$pyridines) is reported.

All the experimental observations with pyridines are consistent with the view that the performance of the catalytic sites are largely modified when the equilibria of additional adsorbed species are involved in the acid-base processes.

Table 2

Back titration of nitroanilines by pyridines in $\mathrm{CF}_{3} \mathrm{SO}_{3} \mathrm{H} / \mathrm{SiO}_{2}$ at $25^{\circ} \mathrm{C}$

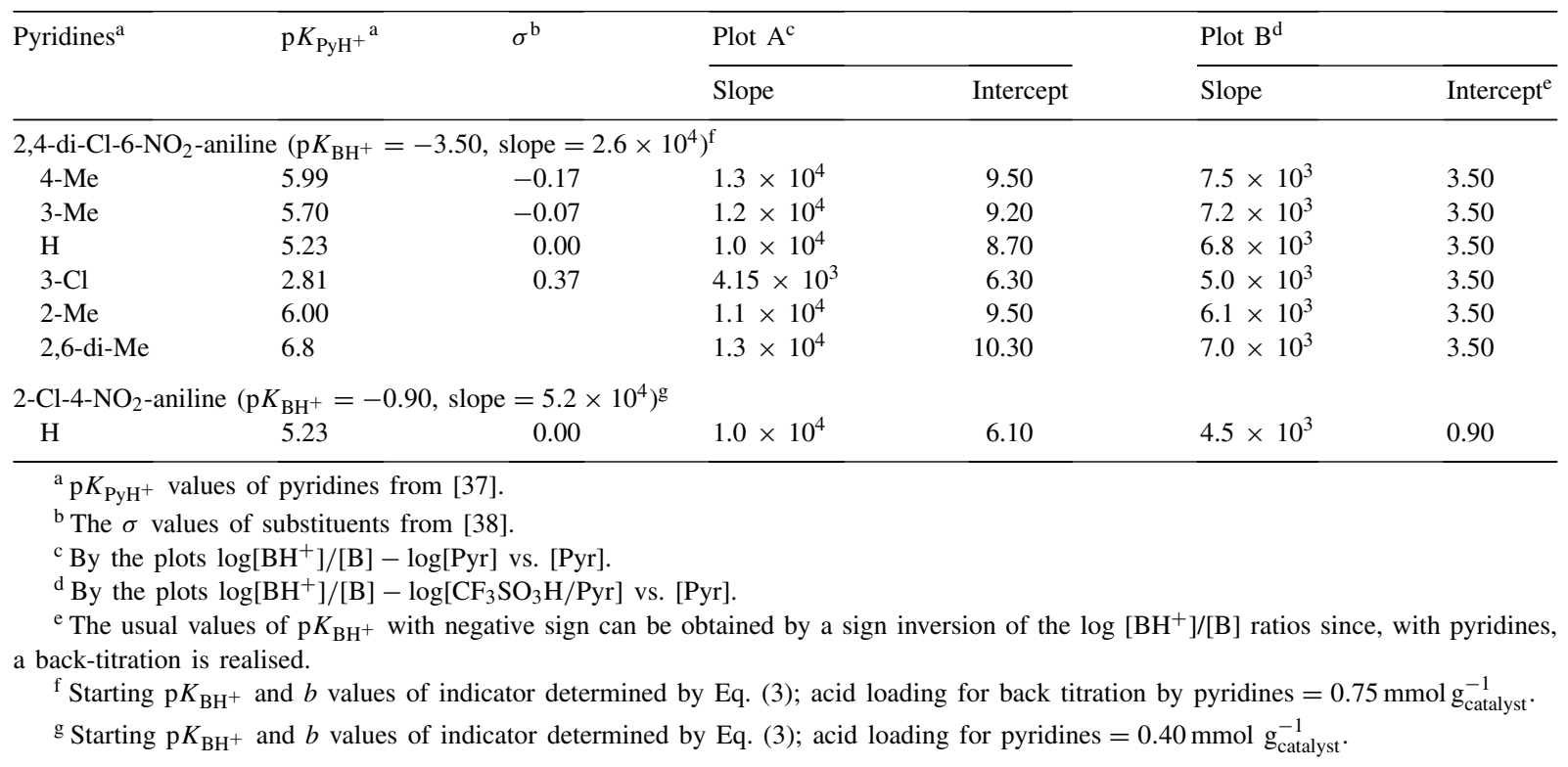




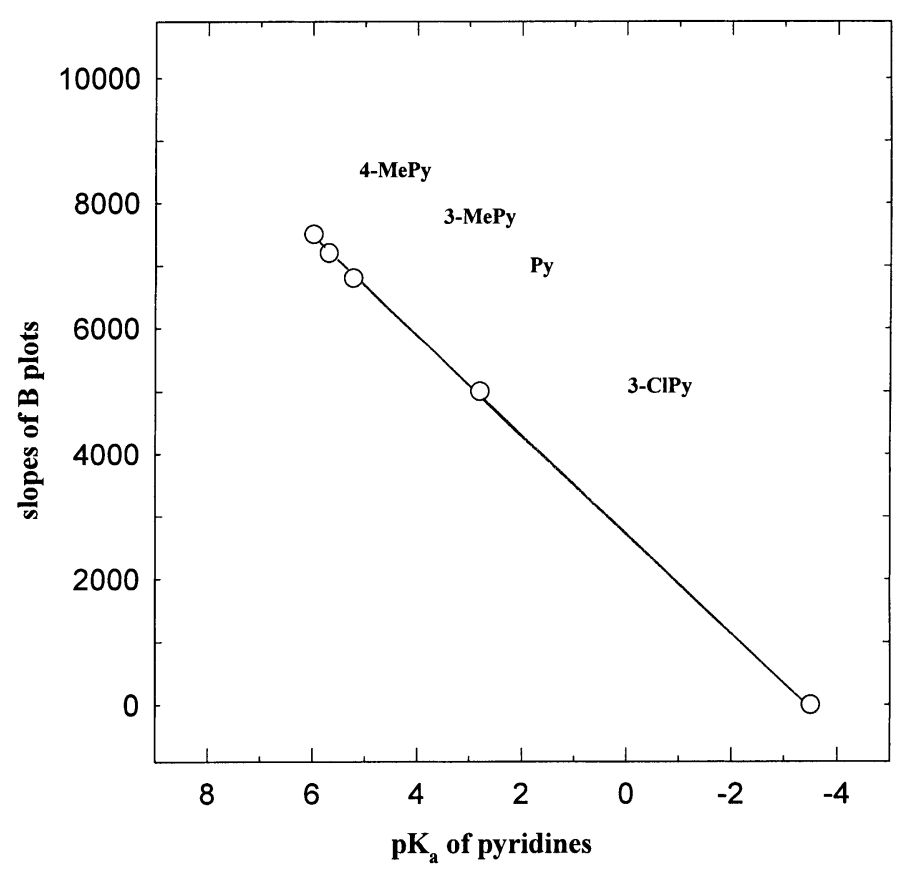

Fig. 3. Back titration of 2,4-diCl-6- $\mathrm{NO}_{2}$-aniline by pyridines in $\mathrm{CF}_{3} \mathrm{SO}_{3} \mathrm{H} / \mathrm{SiO}_{2}$ at $25^{\circ} \mathrm{C}$. Slopes of (B) plots vs. p $K_{\mathrm{PyrH}^{+}}$of pyridines (slopes and $\mathrm{p} K_{\mathrm{PyrH}^{+}}$values in Table 2).

\subsection{Protonation studies in aqueous acid mixtures}

Previous studies in aqueous strong acids (HA) have shown that "acidity" and "protonating ability" are parameters describing different properties of non ideal acid systems [23-26]. The first is related to ionisation-dissociation process of $\mathrm{HA}$ in the $\left(\mathrm{HA}+\mathrm{H}_{2} \mathrm{O}\right)$ mixtures, the second to protonation process of weak bases in the ( $\mathrm{HA}+\mathrm{H}_{2} \mathrm{O}+\mathrm{B}$ ) mixtures. In aqueous TFMSA, for instance, whose dissociation (equilibrium 5) is described by the thermodynamic Eq. (6)

$\mathrm{HA} \rightleftharpoons \mathrm{H}^{+}+\mathrm{A}^{-}$

$\mathrm{p} K_{\mathrm{HA}}=\log \frac{[\mathrm{HA}]}{\left[\mathrm{A}^{-}\right]}-\log \left[\mathrm{H}^{+}\right]-\log \left(\frac{f_{\mathrm{A}^{-}} f_{\mathrm{H}^{+}}}{f_{\mathrm{HA}}}\right)$

an "activity coefficient function" or $\mathrm{Mc}(\mathrm{s})$ and an "acidity function of the solvent" or $\mathrm{Ac}(\mathrm{s})$ - defined, respectively, by Eqs. (7) and (8) - have been determined using the Eqs. (9) and (10) (where $\mathrm{p} K_{\mathrm{a}}=\mathrm{p} K$ apparent instead of termodinamic $\mathrm{p} K$ or $\left.\mathrm{p} K_{\mathrm{HA}}\right)$.

$$
\begin{aligned}
& \operatorname{Mc}(\mathrm{s})=-\log \left(\frac{f_{\mathrm{A}^{-}} f_{\mathrm{H}^{+}}}{f_{\mathrm{HA}}}\right) \\
& -\log \left[\mathrm{H}^{+}\right]+\operatorname{Mc}(\mathrm{s})=\mathrm{Ac}(\mathrm{s}) \\
& \mathrm{p} K_{\mathrm{a}}-\left[\log \frac{[\mathrm{HA}]}{\left[\mathrm{A}^{-}\right]}-\log \left[\mathrm{H}^{+}\right]\right]=\mathrm{Mc}(\mathrm{s}) \\
& \mathrm{p} K_{\mathrm{a}}-\log \frac{[\mathrm{HA}]}{\left[\mathrm{A}^{-}\right]}=-\log \left[\mathrm{H}^{+}\right]+\mathrm{Mc}(\mathrm{s})=\mathrm{Ac}(\mathrm{s})
\end{aligned}
$$

The Mc(s) function is a measure of the deviations from the ideality of the aqueous acidic medium under investigation. The $\mathrm{Ac}(\mathrm{s})$ is an extension of the $\mathrm{pH}$ scale in concentrated aqueous acid solutions. In Fig. 4, the $\operatorname{Mc}(\mathrm{s})$ and the $\operatorname{Ac}(\mathrm{s})$ functions of TFMSA are shown. Practically, the functions were estimated from the degrees of dissociation $(\alpha)$ of HA in water, being $\left\{\log [\mathrm{HA}] /\left[\mathrm{A}^{-}\right]-\log \left[\mathrm{H}^{+}\right]\right\}=\left\{\log \left[(1-\alpha) / \alpha^{2} c\right]\right\}$. The $\alpha$ values were obtained by Raman measurements of the ionisable sulfonic group $\left(\mathrm{CF}_{3} \mathrm{SO}_{3}{ }^{-}\right.$or $\left.\mathrm{A}^{-}\right)$in the range between 0.1 and $100 \mathrm{wt} . \% \mathrm{CF}_{3} \mathrm{SO}_{3} \mathrm{H}[25,27]$.

The $\mathrm{p} K_{\mathrm{a}}$ value $=-3.60$ was used for TFMSA, already determined by studying the equilibria of some 


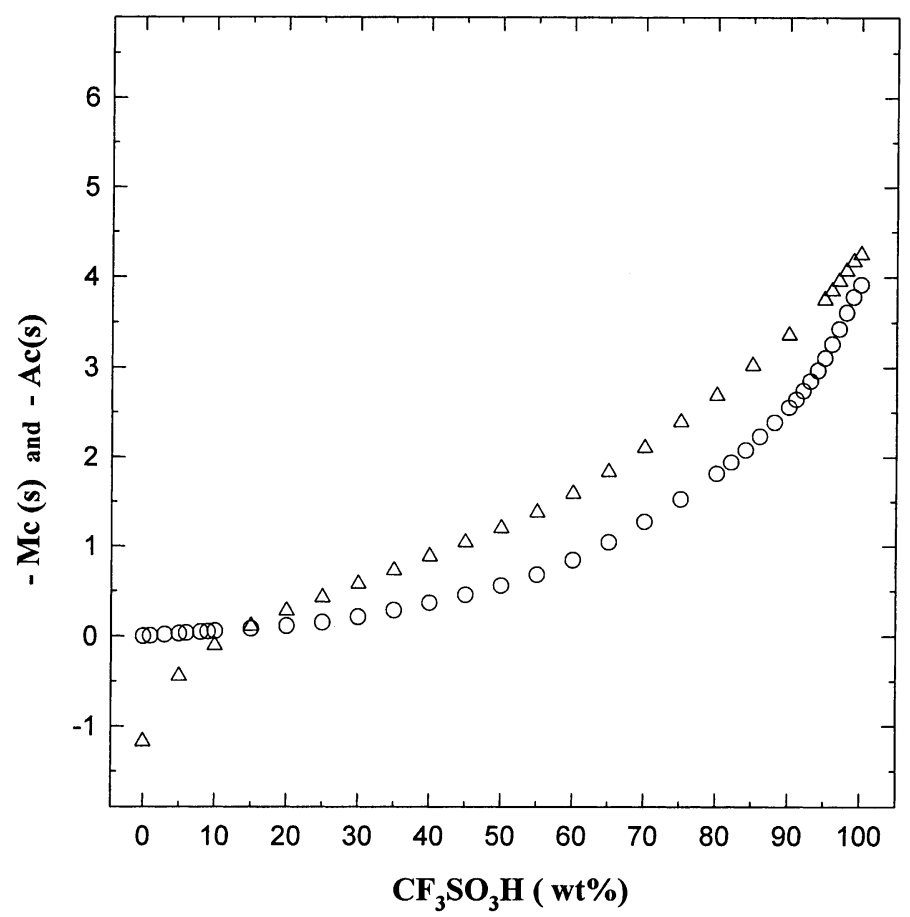

Fig. 4. Plot of $\mathrm{Mc}(\mathrm{s})(\mathrm{O})$ and $\mathrm{Ac}(\mathrm{s})(\triangle)$ vs. wt. $\% \mathrm{CF}_{3} \mathrm{SO}_{3} \mathrm{H}$ in aqueous solutions. $\mathrm{Mc}(\mathrm{s})$ and $\mathrm{Ac}(\mathrm{s})$ at $25^{\circ} \mathrm{C}$ estimated by Eqs. (9) and (10). Values from [23].

alkanesulfonic acids $\left(\mathrm{Y}_{-} \mathrm{SO}_{3} \mathrm{H}\right.$ with $\mathrm{Y}=\mathrm{Me}-$, Et-, $\left.\mathrm{Pr}-, \mathrm{Bz}^{-}, \mathrm{CF}_{3}{ }^{-}\right)$as solutes in sulfuric acid [28].

The protonation of $\mathrm{B}$ according to equilibrium (1) has been estimated by UV measurements of the $\left(\mathrm{CF}_{3} \mathrm{SO}_{3} \mathrm{H}+\mathrm{H}_{2} \mathrm{O}+\mathrm{B}\right)$ mixtures, using progressively $\mathrm{B}_{1}, \mathrm{~B}_{2}, \ldots, \mathrm{B}_{n}$ weaker bases as increases the acid concentration [23-26]. In this study, the $\left.\left(\log \left[\mathrm{BH}^{+}\right]\right] /[\mathrm{B}]\right)$ ratios of solutes and the $\log \left[\mathrm{H}^{+}\right]$ values of the solvent have been used as source of experimental data for a comparison of indicators, by Eq. (11).

$$
\begin{aligned}
& \log \frac{\left[\mathrm{B}_{1} \mathrm{H}^{+}\right]}{\left[\mathrm{B}_{1}\right]}-\log \left[\mathrm{H}^{+}\right] \\
& =n_{b_{1} b_{2}} \log \frac{\left[\mathrm{B}_{2} \mathrm{H}^{+}\right]}{\left[\mathrm{B}_{2}\right]}-\log \left[\mathrm{H}^{+}\right] \\
& \log \left(\frac{f_{\mathrm{B}_{1}} f_{\mathrm{H}^{+}}}{f_{\mathrm{B}_{1} \mathrm{H}^{+}}}\right)=n_{b_{1} b_{2}} \log \left(\frac{f_{\mathrm{B}_{2}} f_{\mathrm{H}^{+}}}{f_{\mathrm{B}_{2} \mathrm{H}^{+}}}\right)
\end{aligned}
$$

The linear relationship observed by (11) or (11') allows one to obtain an "activity coefficient function of indicators" (Eq. (12)) and a description of equilibria by the empirical Eq. (13).

$$
\begin{aligned}
& \operatorname{Mc}\left(\mathrm{B}^{*}\right)=-\log \left(\frac{f_{\mathrm{B}^{*}} f_{\mathrm{H}^{+}}}{f_{\mathrm{B}^{*} \mathrm{H}^{+}}}\right) \\
& \mathrm{p} K_{\mathrm{BH}^{+}}=\log \frac{\left[\mathrm{BH}^{+}\right]}{[\mathrm{B}]}-\log \left[\mathrm{H}^{+}\right]+n_{b b^{*}} \operatorname{Mc}\left(\mathrm{B}^{*}\right)
\end{aligned}
$$

The protonation of $\mathrm{B}$ outside the range of $\mathrm{pH}$ is, then, characterised by two independent parameters: $\left(\mathrm{p} K_{\mathrm{BH}^{+}}\right)$and $\left(n_{b b^{*}}\right)$ related, respectively, to the intercepts $\left(\mathrm{p} K_{\mathrm{BH}^{+}}\right)$and slopes $\left(n_{b b^{*}}\right)$ of the plots $\left(\log \left[\mathrm{BH}^{+}\right] /[\mathrm{B}]-\log \left[\mathrm{H}^{+}\right]\right)$versus $\mathrm{Mc}\left(\mathrm{B}^{*}\right)$. The $\mathrm{Mc}\left(\mathrm{B}^{*}\right)$ function is a measure of the deviations from the ideality of aqueous acidic media, referred to that of a weak base $\left(\mathrm{B}^{*}\right)$ protonating at low acid concentrations and chosen as standard state [23-26]. In Table 3, some equilibrium data obtained by the Mc procedure are reported.

The practical determination of two indipendent "activity coeffficient functions" allows a comparison of the equilibria (1) and (5) and in $\mathrm{CF}_{3} \mathrm{SO}_{3} \mathrm{H}, \mathrm{CH}_{3} \mathrm{SO}_{3} \mathrm{H}$, 
Table 3

Protonation equilibria of weak bases in concentrated aqueous solutions of $\mathrm{CF}_{3} \mathrm{SO}_{3} \mathrm{H}$ and $\mathrm{H}_{2} \mathrm{SO}_{4}$ at $25^{\circ} \mathrm{C}$

\begin{tabular}{|c|c|c|c|c|}
\hline & \multicolumn{2}{|c|}{$\mathrm{CF}_{3} \mathrm{SO}_{3} \mathrm{H}^{\mathrm{a}}$} & \multicolumn{2}{|c|}{$\mathrm{H}_{2} \mathrm{SO}_{4}{ }^{\mathrm{b}}$} \\
\hline & $n_{b b^{*}}{ }^{\mathrm{c}}$ & $n_{\text {is }}^{\mathrm{d}}$ & $n^{* \mathrm{e}}$ & $\mathrm{p} K_{\mathrm{BH}^{+}}{ }^{\mathrm{f}}$ \\
\hline \multicolumn{5}{|l|}{ Nitroanilines } \\
\hline $14-\mathrm{NO}_{2}$ & 0.95 & 2.00 & 0.85 & 1.00 \\
\hline $22-\mathrm{NO}_{2}$ & 1.00 & 2.12 & 1.00 & -0.27 \\
\hline $32-\mathrm{Cl}-4-\mathrm{NO}_{2}$ & 1.04 & 2.23 & 0.98 & -0.90 \\
\hline 4 4-Cl-2-NO & 1.07 & 2.28 & 1.02 & -1.05 \\
\hline 5 2,4-di-Cl-6- $\mathrm{NO}_{2}$ & 1.25 & 2.62 & 1.16 & -3.50 \\
\hline $62,4-$ di- $-\mathrm{NO}_{2}$ & 1.40 & 2.95 & 1.30 & -5.25 \\
\hline 7 2,6-di- $\mathrm{NO}_{2}$ & 1.45 & 3.00 & 1.15 & -5.90 \\
\hline 8 2-Br-4,6-di- $\mathrm{NO}_{2}$ & 1.60 & 3.28 & 1.19 & -7.80 \\
\hline 9 3-Me-2,4,6-tri- $\mathrm{NO}_{2}$ & 1.75 & 3.73 & 1.37 & -10.40 \\
\hline $102,4,6$-tri- $\mathrm{NO}_{2}$ & 1.79 & 3.78 & 1.20 & -10.70 \\
\hline 11 3-Br-2,4,6-tri- $\mathrm{NO}_{2}$ & 1.96 & 4.16 & 1.47 & -12.25 \\
\hline \multicolumn{5}{|l|}{ Nitrobenzenes } \\
\hline $124-\mathrm{NO}_{2}-m$-xylene & 1.46 & 3.10 & & -10.00 \\
\hline $134-\mathrm{NO}_{2}$-toluene & 1.50 & 3.35 & & -11.50 \\
\hline 14 Nitrobenzene & 1.84 & 3.90 & & -15.00 \\
\hline 15 4-Cl-nitrobenzene & 1.96 & 4.15 & & -16.50 \\
\hline 16 Mesytilene & 1.9 & 4.03 & & -12.70 \\
\hline $17 \mathrm{HNO}_{3} \rightarrow \mathrm{NO}_{2}^{+}$ & & 3.37 & 2.46 & -17.30 \\
\hline
\end{tabular}

${ }^{a}$ Data from $[23,26,28,30]$.

${ }^{\mathrm{b}}$ Data from $[25,26]$.

${ }^{\mathrm{c}}$ Slopes of the plots $\log \left[\mathrm{BH}^{+}\right] /[\mathrm{B}]-\log \left[\mathrm{H}^{+}\right]$vs. $\mathrm{Mc}\left(\mathrm{B}^{*}\right)$.

${ }^{\mathrm{d}}$ Slopes of the plots $\log \left[\mathrm{BH}^{+}\right] /[\mathrm{B}]-\log \left[\mathrm{H}^{+}\right]$vs. $\mathrm{Mc}(\mathrm{s})$.

${ }^{\text {e }}$ Slopes of the plots $\log \left[\mathrm{BH}^{+}\right] /[\mathrm{B}]-\log \left[\mathrm{H}^{+}\right]$vs. $\mathrm{Mc}^{*}$; in $\mathrm{H}_{2} \mathrm{SO}_{4}$ where two equilibria are involved; $\mathrm{Mc}^{*}(\mathrm{~s})=$ $\left[\mathrm{Mc}\left(\mathrm{HSO}_{4}^{-}\right)+\mathrm{Mc}^{\circ}\left(\mathrm{H}_{2} \mathrm{SO}_{4}\right)\right]$. For nitroanilines and triphenylmethanols, two different linear dependences below and above $80 \mathrm{wt} . \% \mathrm{H}_{2} \mathrm{SO}_{4}$ have also been recognised $[25,26]$.

${ }^{\mathrm{f}}$ Intercepts of the plots $\log \left[\mathrm{BH}^{+}\right] /[\mathrm{B}]-\log \left[\mathrm{H}^{+}\right]$vs. Mc functions in $\mathrm{CF}_{3} \mathrm{SO}_{3} \mathrm{H}$ and in $\mathrm{H}_{2} \mathrm{SO}_{4}$.

$\mathrm{HBr}, \mathrm{HClO}_{4}, \mathrm{HNO}_{3}, \mathrm{H}_{2} \mathrm{SO}_{4}$, plots of $\mathrm{Mc}(\mathrm{i})$ versus $\mathrm{Mc}(\mathrm{s})$ exhibit linear trends with $n_{\text {is }} \neq 1$. In $\mathrm{CF}_{3} \mathrm{SO}_{3} \mathrm{H}$, $n_{\text {is }}=2.12$ has been found.

The acid-base relationships satisfying Eq. (14) or Eq. (14') suggest that the $n_{\text {is }}$ parameters are involved in the proton-transfer process from $\left(\mathrm{H}^{+} \mathrm{A}^{-}\right)_{\mathrm{aq}}$ to $\left(\mathrm{BH}^{+} \mathrm{A}^{-}\right)_{\mathrm{aq}}$ species, whose values can be taken as a measure of the "protonating ability" of an acid towards a base.

$$
\begin{aligned}
& \operatorname{Mc}(\mathrm{i})=n_{\text {is }} \mathrm{Mc}(\mathrm{s}) \\
& -\log \left(\frac{f_{\mathrm{B}^{*}} f_{\mathrm{H}^{+}}}{f_{\mathrm{B}^{*} \mathrm{H}^{+}}}\right)=-n_{\text {is }} \log \left(\frac{f_{\mathrm{A}^{-}} f_{\mathrm{H}^{+}}}{f_{\mathrm{HA}}}\right)
\end{aligned}
$$

Further results are also consistent with the view that the "protonating ability of a given acid towards a solute is characterised by the energetic proton transfer process of the specific acid-base pair". Detailed observations are in Fig. 5 where the linear dependences between $n_{\text {is }}$ and $\mathrm{p} K_{\mathrm{BH}^{+}}$values of indicators undergoing protonation between 0.1 and $100 \mathrm{wt} . \% \mathrm{CF}_{3} \mathrm{SO}_{3} \mathrm{H}$ are reported. The behaviour of solutes also shows: (i) a progressive increase in the $n_{\text {is }}$ values for increasingly weaker bases with analogous basic site; (ii) a linear dependences between $n_{\text {is }}$ and $\mathrm{p} K_{\mathrm{BH}^{+}}$values and intercept at the $\mathrm{p} K_{\mathrm{W}}$ of water, being $n_{\mathrm{is}}=0$ for water; (iii) a specific dependence of $n_{\text {is }}$ for classes of indicators (see Fig. 5a and b).

The results deduced by different studies in the solid phase supports analogous conclusions [24,33,34]. Consistent with the previous results are the slopes of 2,4-diCl-6- $\mathrm{NO}_{2}$-aniline whose values are modified according to the basic strength of pyridines used as additional adsorbed species (see Table 2). The LFER given in Figs. 3 and 5 clearly suggest reliable descriptions of the acid-base interactions in the systems under investigations.

In the light of the new results, the $H_{x}\left(H_{x}=H_{0}, H_{\mathrm{R}}\right.$, $H_{\mathrm{A}}, H_{\mathrm{I}}$, etc.) acidity functions determined by using the protonations of the indicators, cannot be accepted as a true measure of acidity. Indeed reliable "Ac(i) acidity functions", suitable to be correlated with the "Ac(s) or $\mathrm{pH}$ scales of the solvents", can be obtained by Eq. (15) rather than by Eq. (16) adopted in the rather simplified Hammett procedure. From a practical point of view, the Ac(i) and $H_{x}$ differ by a factor (i.e. $n_{\text {is }}$ parameter), responsible for the progressive inconsistency of the $H_{x}$ values as we are going from dilute to concentrated acid solutions.

$$
\begin{aligned}
& \operatorname{Ac}(\mathrm{i})=\left\{-n_{\mathrm{is}} \log \left[\mathrm{H}^{+}\right]+\operatorname{Mc}(\mathrm{i})\right\} \\
& H_{x}=-\log \left[\mathrm{H}^{+}\right]-\log \left(\frac{f_{\mathrm{B}} f_{\mathrm{H}^{+}}}{f_{\mathrm{BH}^{+}}}\right)
\end{aligned}
$$

\subsection{Acid-catalysed reactions}

Mesitylene and nitrobenzenes are weak bases whose protonation equilibria can be easily determined in aqueous TFMSA between 90 and $100 \mathrm{wt} . \%$, but non in an analogous range of sulfuric acid (see Table 3) $[23,26,30]$. It suggests an high catalytic 

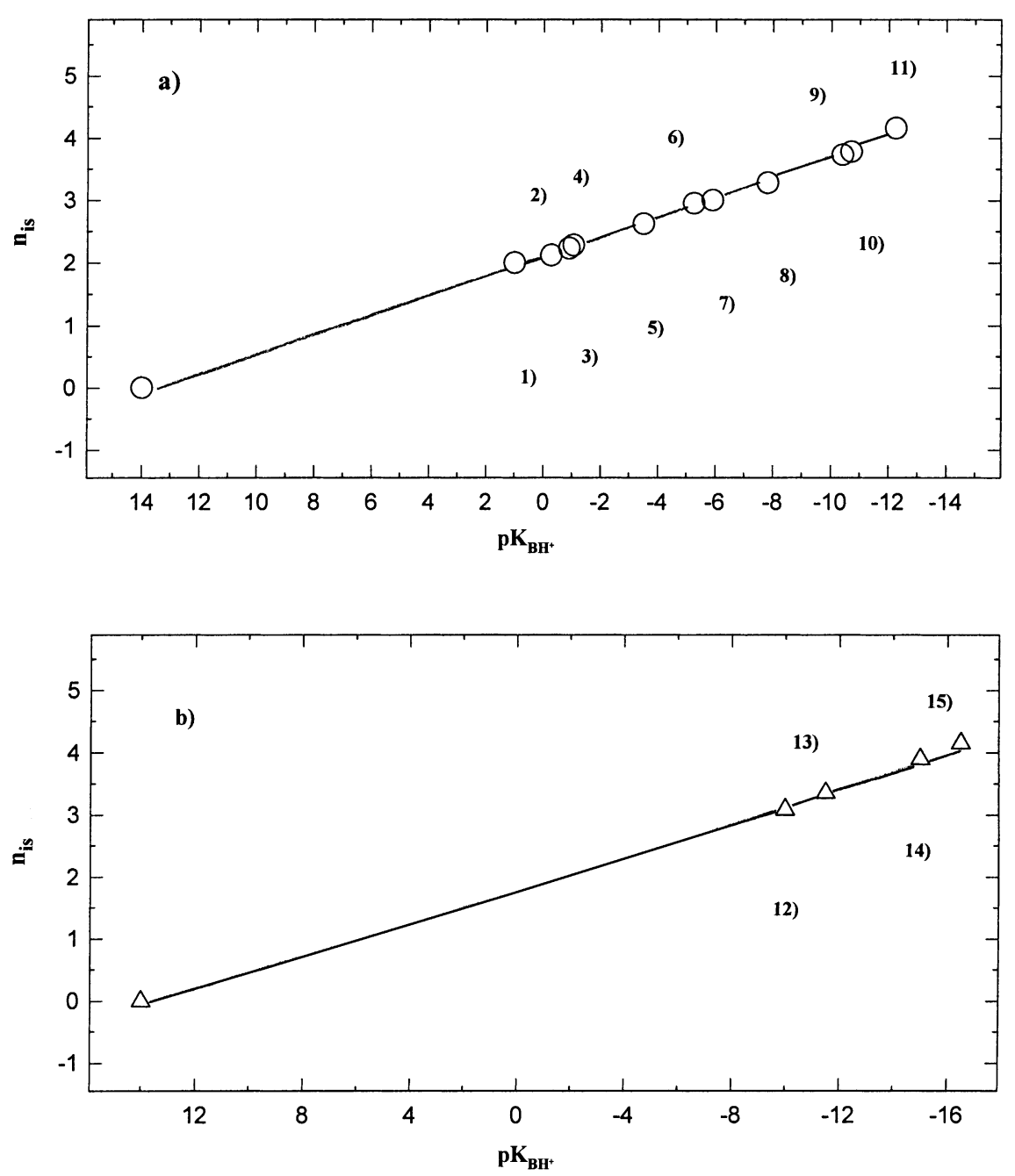

Fig. 5. Protonation equilibria of weak bases in aqueous $\mathrm{CF}_{3} \mathrm{SO}_{3} \mathrm{H}$ at $25^{\circ} \mathrm{C}$. Plot of $n_{\text {is }}$ vs. $\mathrm{p} K_{\mathrm{BH}^{+}}\left(n_{\text {is }}\right.$ and $\mathrm{p} K_{\mathrm{BH}^{+}}$values in Table 3). (a) Nitroanilines, slope of the plot $\left(N_{\text {is }}\right)=0.15$. (b) Nitrobenzenes, slope of the plot $\left(n_{\text {is }}\right)=0.13$.

performance of TFMSA for acid catalysed reactions with high acid requirements. In sulfuric acid, on the contrary, the apparence of new species (i.e. $\mathrm{H}_{3} \mathrm{SO}_{4}{ }^{+}$, $\mathrm{H}_{2} \mathrm{~S}_{2} \mathrm{O}_{7}, \mathrm{SO}_{3}$, etc.) can lead to complications or to undesiderable by-products for indicators suitable to be sulfonated [26].

Kinetic studies related to nitrations of aromatic compounds show that TFMSA between 50 and $80 \mathrm{wt} . \%$ exhibit nitrating properties analogous to those observed in sulfuric acid [31]. In this range, for instance, the observed rate constants for mesitylene, toluene, benzene, bromobenzene are very close to each other, if compared at the same mole fraction of acid. However, in the range 80-100 wt.\% suitable for nitration of deactivated compounds, the rate of methyl phenyl sulfone in TFMSA is reduced by a factor of 8 . Obviously the reduction can be related neither to aromatic protonation nor to concentration of nitronium ion which, in both systems is practically the same at the same mole fraction [25,29,31].

It has been suggested that the different nitration rates of methylphenyl sulfone in reaction media where the water behaves as solute are related to the different 
Table 4

Nitration and esterification of aromatic compounds over solid acid catalysts

\begin{tabular}{|c|c|c|c|c|c|c|c|c|c|}
\hline \multirow[t]{3}{*}{ Compounds } & & & \multicolumn{7}{|l|}{ Catalysts } \\
\hline & & & \multicolumn{2}{|c|}{$\mathrm{CF}_{3} \mathrm{SO}_{3} \mathrm{H} / \mathrm{SiO}_{2}$} & & \multicolumn{2}{|c|}{$\mathrm{H}_{2} \mathrm{SO}_{4} / \mathrm{SiO}_{2}$} & \multicolumn{2}{|c|}{$\left(\mathrm{CF}_{3} \mathrm{SO}_{3} \mathrm{H}+\mathrm{H}_{2} \mathrm{SO}_{4}\right) / \mathrm{SiO}_{2}$} \\
\hline & & & $(\mathrm{mmol} / \mathrm{g})^{\mathrm{a}}$ & Yield $(\%)^{\mathrm{b}}$ & & $(\mathrm{mmol} / \mathrm{g})^{\mathrm{a}}$ & Yield $(\%)^{\mathrm{b}}$ & $(\mathrm{meq} / \mathrm{g})^{\mathrm{c}}$ & Yield $(\%)^{\mathrm{b}}$ \\
\hline \multirow{4}{*}{\multicolumn{3}{|c|}{$\begin{array}{l}\text { Nitration in dichloromethane at } 25^{\circ} \mathrm{C} \text { of } \\
\mathrm{Ar}-\mathrm{CH}_{3}\end{array}$}} & & & & & & & \\
\hline & & & 1.1 & 100 & & 1.1 & 100 & 3.4 & 100 \\
\hline & & & 2.3 & 100 & & 4.4 & 100 & 6.6 & 100 \\
\hline & & & 3.3 & 100 & & & & & \\
\hline \multirow{2}{*}{\multicolumn{3}{|c|}{ Ortho- $\mathrm{NO}_{2}-\mathrm{Ar}-\mathrm{CH}_{3}$}} & 1.1 & 4.1 & & 1.1 & 80 & 3.4 & 74 \\
\hline & & & 2.3 & 25.5 & & 4.4 & 80 & 6.6 & 80 \\
\hline \multirow{3}{*}{\multicolumn{3}{|c|}{$\mathrm{Ar}-\mathrm{NO}_{2}$}} & 1.1 & Starting material & & 1.1 & 21.8 & 3.4 & 18.9 \\
\hline & & & 2.3 & Starting material & & 2.2 & 28.7 & 6.6 & 57.7 \\
\hline & & & 3.3 & Starting material & & 4.4 & 45.1 & & \\
\hline \multirow{3}{*}{\multicolumn{3}{|c|}{$\begin{array}{l}\text { Ar S- }-\mathrm{CH}_{3}{ }^{\mathrm{d}} \\
\text { Ar SO-CH} \\
\text { Ar } \mathrm{SO}_{2}-\mathrm{CH}_{3}\end{array}$}} & 3.3 & 100 & & 4.4 & 100 & & \\
\hline & & & 3.3 & Starting material & & 4.4 & 78 & & \\
\hline & & & 3.3 & Starting material & & 4.4 & 17 & & \\
\hline & \multicolumn{3}{|c|}{$\mathrm{CF}_{3} \mathrm{SO}_{3} \mathrm{H} / \mathrm{SiO}_{2}$} & $\mathrm{H}_{2} \mathrm{SO}_{4} / \mathrm{SiO}_{2}$ & & & \multicolumn{3}{|c|}{$\left(\mathrm{CF}_{3} \mathrm{SO}_{3} \mathrm{H}+\mathrm{H}_{2} \mathrm{SO}_{4}\right) / \mathrm{SiO}_{2}$} \\
\hline & \multirow[t]{2}{*}{$(\mathrm{mmol} / \mathrm{g})^{\mathrm{a}}$} & \multicolumn{2}{|c|}{ Yield $(\%)^{\mathrm{f}}$} & $(\mathrm{mmol} / \mathrm{g})^{\mathrm{a}}$ & \multicolumn{2}{|c|}{ Yield $(\%)^{\mathrm{f}}$} & $(\mathrm{meq} / \mathrm{g})^{\mathrm{a}}$ & \multicolumn{2}{|c|}{ Yield $(\%)^{\mathrm{f}}$} \\
\hline & & $70^{\circ} \mathrm{C}$ & $110^{\circ} \mathrm{C}$ & & $70^{\circ} \mathrm{C}$ & $110^{\circ} \mathrm{C}$ & & $70^{\circ} \mathrm{C}$ & $110^{\circ} \mathrm{C}$ \\
\hline \multicolumn{10}{|c|}{ Esterification with methanol in toluene } \\
\hline Mesitoic acid & 1.1 & 2 & 35 & 1.1 & 5 & 100 & 3.4 & 15 & 100 \\
\hline Mesitoic acid & 2.3 & 45 & 87 & 4.4 & 62 & 100 & 6.6 & 46 & 100 \\
\hline
\end{tabular}

\footnotetext{
${ }^{\text {a }}$ Acid $(\mathrm{mmol}) / \mathrm{g}_{\text {catalyst }}$.

${ }^{\mathrm{b}}$ Yield\% of nitrocompounds after $48 \mathrm{~h}$.

${ }^{\mathrm{c}}$ For these catalysts where a mixture of different acids is used, the meq of acid $/ \mathrm{g}_{\text {catalyst }}$ have been determined.

${ }^{\mathrm{d}}$ Product $=\mathrm{Ar} \mathrm{SOCH}_{3}$.

${ }^{\mathrm{e}}$ Mixture of nitrocompounds (78\%) and $\mathrm{Ar} \mathrm{SO}_{2} \mathrm{CH}_{3}(22 \%)$.

${ }^{\mathrm{f}}$ Yield $\%$ of methyl mesitoate after $1 \mathrm{~h}$.
}

ability of the pure solvents to dissociate ion pairs into free, solvated ions according to the process

$$
\mathrm{AH}+\mathrm{H}_{2} \mathrm{O} \rightleftharpoons \mathrm{A}^{-} \mathrm{H}_{3} \mathrm{O}+\rightleftharpoons \mathrm{A}^{-}+\mathrm{H}_{3} \mathrm{O}^{+}
$$

In Table 4, new studies are reported, where the catalytic properties of supported triflic and sulfuric acids were compared in the nitrations of activated and deactivated compounds as well as in the esterification of mesitoic acid, using experimental conditions analogous to the ones already discussed in the previous kinetic studies $[39,40]$. As concerns the esterification, a substrate with high acid requirements for the conversion reagents products has been chosen since the 2,4,6-triMe-ArC $=\mathrm{O}^{+}$mesitoyl cations, from mesitoic acid, can be formed and esterified in very concentrated acid systems (>92 wt.\% $\mathrm{H}_{2} \mathrm{SO}_{4}$ ) [39]).
The general trend observed towards two different reaction paths shows that TFMSA in liquid and solid phase is a less effective catalyst compared to sulfuric acid as expected when ion-pairs effects on equilibria and rates are occurring. In these case, several factors including contributions from dissociation process and mobility of the species will cause a decrease in rates and yields of products. Agreement with the observed behaviour comes from spectroscopic and kinetic studies related to equilibria and reactivity of TFMSA [27-29,31]. It is also well known that $\mathrm{HNO}_{3}$ and $\mathrm{CF}_{3} \mathrm{SO}_{3} \mathrm{H}$, in the reaction between the pure reagents, combine to form a solid identified as a mixture of $\mathrm{CF}_{3} \mathrm{SO}_{3}{ }^{-} \mathrm{NO}_{2}{ }^{+}$and $\mathrm{CF}_{3} \mathrm{SO}_{3}{ }^{-} \mathrm{H}_{3} \mathrm{O}^{+}$[41].

The additional experimental observations obtained by using $\left(\mathrm{CF}_{3} \mathrm{SO}_{3} \mathrm{H}+\mathrm{H}_{2} \mathrm{SO}_{4}\right) / \mathrm{SiO}_{2}$ as catalysts are 
also of interest. In this case, yields of products comparable (or higher) to those obtained by $\mathrm{H}_{2} \mathrm{SO}_{4} / \mathrm{SiO}_{2}$ are observed. Further work is in progress for a better understanding of the properties of a catalysts when supported systems with multi-component acids are used.

\subsection{Conclusion}

The TFMSA has been used as model system for studying acidity and catalytic performance in liquid and solid acid catalysts. In the elucidation of the problem of acidity, the results are consistent with the view that, in both phases, the "protonating ability" of a given acid (HA) towards a solute (B) is the parameter of interest of non ideal acid systems, characterised by the energetic proton transfer process of the specific acid-base pair under investigation.

In the elucidation of the catalytic performance, TFMSA, compared to sulfuric acid, has be found to be a less effective catalyst in the nitrations and esterifications of aromatic compounds in spite of its high effectiveness as protonating agent.

\section{References}

[1] A. Senning, Chem. Rev. 65 (1965) 385.

[2] J. Grondin, R. Sagnes, A. Commeyras, Bull. Soc. Chim. Fr. 11 (1976) 1779.

[3] R.D. Howells, J.D. McCown, Chem. Rev. 77 (1977) 69.

[4] D.G. Russell, J.B. Senior, Can. J. Chem. 52 (1974) 2975.

[5] D.G. Russell, J.B. Senior, Can. J. Chem. 58 (1980) 22.

[6] M. Leuchs, G. Zundel, J. Chem. Soc., Faraday Trans. II 74 (1978) 2256.

[7] M. Leuchs, G. Zundel, Can. J. Chem. 58 (1980) 311.

[8] G. Zundel, J. Fritsch, in: R.R. Dogonadze, E. Kalman, A.A. Kornyshev, J. Ulstrup (Eds.), The Chemical Physics of Solvation, Part B, Elsevier, Amsterdam, 1986.

[9] G.A. Olah, G.K. Surya Prakash, J. Sommer, Superacids, Wiley, New York, 1985.

[10] J.W. Brockington, R.H. Bennett, US Patent 3970721 (1976), assigned to Texaco Inc.

[11] J.F. Joly, C. Marcilly, E. Benazzi, US Patent 5336833 (1994), assigned to Inst. Francais du Petrol (Fr).

[12] L. Montanari, C. Perego, M.G. Clerici, E.P. 0638363 (1995), assigned to Agip Petroli (It), Eniricerche SPA (It).

[13] P. Sarup, S.I. Hommeltoft, M. Sylvest-Johansen, P. Sogaard-Andersen, in: Proceeding of the DGMK Conference on Catalysis on Solid Acids and Bases, Berlin, Germany, 1996, p. 175.

[14] S.I. Hommeltoft, E.P. 0987237A (2000), assigned to Topsoe Haldor AS (DK).

[15] G.A. Olah, G.K. Surya Prakash, J. Sommer, Science 206 (1979) 13.

[16] M.A. Harmer, W.E. Farneth, Q. Sun, J. Am. Chem. Soc. 118 (1996) 7708.

[17] F.J. Waller, R.W. Van Scoyoc, Chemtech 17 (1987) 438.

[18] M. Misono, T. Okuhara, Chemtech 23 (1993) 23.

[19] A. Corma, Chem. Rev. 95 (1995) 559.

[20] E. Brunner, Catal. Today 38 (1997) 361.

[21] L.P. Hammett, Physical Organic Chemistry, McGraw-Hill, Kogakusha, Tokyo, 1970.

[22] C.H. Rochester, Acidity Functions, Academic Press, London, 1970.

[23] N.C. Marziano, A. Tomasin, C. Tortato, Org. React. (Estonia) 30 (1996) 29, 39.

[24] N.C. Marziano, C. Tortato, L. Ronchin, C. Bianchi, Catal. Lett. 56 (1998) 159.

[25] N.C. Marziano, A. Tomasin, C. Tortato, J.M. Zaldivar, J. Chem. Soc., Perkin Trans. 2 (1998) 1973.

[26] N.C. Marziano, A. Tomasin, C. Tortato, P. Isandelli, J. Chem. Soc., Perkin Trans. 2 (1998) 2535.

[27] M. Sampoli, N.C. Marziano, C. Tortato, J. Phys. Chem. 93 (1989) 7252.

[28] N.C. Marziano, A. Tomasin, C. Tortato, J. Chem. Soc., Perkin Trans. 2 (1991) 1575.

[29] N.C. Marziano, A. Tomasin, M. Sampoli, J. Chem. Soc., Perkin Trans. 2 (1991) 1995.

[30] N.C. Marziano, C. Tortato, R. Bertani, J. Chem. Soc., Perkin Trans. 2 (1992) 955.

[31] N.C. Marziano, C. Tortato, M. Sampoli, J. Chem. Soc., Perkin Trans. 2 (1991) 423.

[32] R.B. Borade, A. Adnot, S. Kaliaguine, J. Catal. 126 (1990) 6.

[33] N.C. Marziano, C. Tortato, A.A. Sheikh-Osman, J. Riego, J.M. Zaldivar, Org. React. (Estonia) 30 (1996) 49.

[34] N.C. Marziano, C. Tortato, A.A. Sheikh-Osman, J. Riego, J.M. Zaldivar, Org. React. (Estonia) 31 (1997) 87.

[35] B.A. Morrow, A.J. MacFarlan, J. Phys. Chem. 95 (1992) 1395.

[36] H. Chen, D.E. Irish, J. Phys. Chem. 75 (1971) 2672.

[37] A. Albert, E.P. Serjeant, The Determination of Ionization Constants, 3rd Edition, Chapman and Hall, London, 1984.

[38] O. Exner, in: N.B. Chapman, J. Shorter (Eds.), Correlation Analysis in Chemistry, Plenum Press, New York, 1978.

[39] N.C. Marziano, C. Tortato, L. Ronchin, C. Bianchi, Catal. Lett. 64 (2000) 15.

[40] N.C. Marziano, C. Tortato, L. Ronchin, F. Martini, C. Bianchi, Catal. Lett. 58 (1999) 81.

[41] C.L. Coon, W.G. Blucher, M.E. Hill, J. Org. Chem. 38 (1973) 4243. 